\title{
KANDUNGAN NUTRISI SERAT BUAH KELAPA SAWIT YANG DIFERMENTASI DENGAN FESES KERBAU PADA LEVEL YANG BERBEDA
}

\author{
J. JULIANTONI ${ }^{1}$., D. A. MUCRA ${ }^{2}$ DAN D. FEBRINA ${ }^{1}$ \\ Fakultas Pertanian dan Peternakan Universitas Islam Negeri Sultan Syarif Kasim RiauKampus Raja Ali \\ Haji Jl. H.R. Soebrantas KM. 15 Pekanbaru \\ E-Mail: jeprijuliantoni@ymail.com
}

\begin{abstract}
This study was conducted from January to March 2013 in the Laboratory of Nutrition and Chemistry, Faculty of Agriculture and Animal Sciences of the State Islamic University of Sultan Syarif Kasim Riau and analysis of the nutrient content were conducted in Ruminant Nutrition Laboratory of the Faculty of Animal Husbandry, Andalas University in Padang. This study aimed to determine the effect of buffalo feces with different levels of fermentation palm press fiber (PPF) for 21 day against $p H$, fermentation quality, dry matter content, crude fiber, crude protein, ash and BETN. Experiment was arranged in a completely randomized design with 4 treatments and 3 replications. The treatment given is the number of buffalo feces levels $(0 \%, 10 \%, 20 \%$ and $30 \%)$. The results showed that the addition of up buffalo feces fermentation SBKS to $30 \%$ gave highly significant effect $(P<0.0 \mathrm{l})$ on the $\mathrm{pH}$, but not significant effect $(P>0.05)$ increase levels of dry matter, crude protein and BETN, and declining levels of crude fiber and crude fat levels.
\end{abstract}

Keywords: Buffalo feces, fermented, PPF

\section{PENDAHULUAN}

Pakan merupakan faktor utama yang mempengaruhi keberhasilan suatu usaha peternakan. Ketersediaan bahan pakan belakangan ini semakin terbatas. Hal ini disebabkan antara lain oleh meningkatnya harga bahan baku pakan dan semakin menyusutnya lahan bagi pengembangan produksi hijauan akibat penggunaan lahan untuk keperluan pangan dan tempat pemukiman. Salah satu masalah yang dihadapi dalam pengembangan peternakan terutama pada musim kemarau adalah kesulitan untuk mendapatkan pakan baik dari segi kuantitas, kualitas dan ketersediaannya.

Provinsi Riau memiliki luas areal perkebunan yang sangat luas. Pada tahun 2013, areal tanam kelapa sawit di Provinsi Riau 2.399.172 Ha, tahun 2014 meningkat menjadi 2.411.820 Ha (BPS, 2014), kemudian mengalami perkembangan yang signifikan hingga tahun 2015 menjadi 2.424.545 Ha (BPS, 2015). Semakin bertambahnya lahan perkebunan kelapa sawit di Riau, maka semakin melimpah juga limbah yang dihasilkan, salah satunya adalah Serat Buah Kelapa Sawit (SBKS). SBKS berpotensi digunakan sebagai bahan pakan karena pemanfaatannya masih terbatas, hanya digunakan sebagai bahan bakar dalam perebusan buah kelapa sawit dan abu yang dihasilkan digunakan sebagai pupuk.

SBKS memiliki kandungan nutrisi Kadar Air (KA) 8,34\%; Bahan Kering (BK) 91,66\%; Protein Kasar (PK) 4,36\%; Serat Kasar (SK) 32,19\%; Lemak Kasar (LK) 3,58\%; Abu 5,61\% dan BETN 54,26\% (Laboratorium Nutrisi Ruminansia Fakultas Peternakan Unand, 2013). Mucra et al., (2009) melaporkan kecernaan BK dan kecernaan BO SBKS adalah 16,65\% dan $14,15 \%$. 
Kendala dalam pemanfaatan SBKS adalah bersifat volumneous, serat kasar tinggi, protein kasar rendah serta palatabilitas dan daya cerna yang rendah. Adanya kendala tersebut dalam pemanfaatan SBKS, pengolahan dan pemberian perlakuan adalah salah satu pilihannya.

Salah satu teknik pengolahan pakan secara biologis yang dapat meningkatkan kandungan nutrisi dan palatabilitas pakan adalah dengan teknik fermentasi menggunakan feses kerbau (Mucra et al., 2009) dan Febrina (2011) menambahkan produk sampingan kelapa sawit seperti serat buah kelapa sawit (SBKS) dapat difermentasi untuk menghasilkan pakan yang berkualitas tinggi, palatable dan stabil. Rahayu (2013) melaporkan bahwa bakteri selulolitik yang terlibat dalam fermentasi menggunakan feses kerbau pada ransum berbahan limbah perkebunan kelapa sawit adalah Fibrobacter sp1., Fibrobacter sp2., Fibrobacter sp3., Cellulomonas sp., Rumincoccus sp 1., Rumincoccus sp2.

Penambahan feses kerbau sampai level $6 \%$ pada fermentasi serat buah kelapa sawit pada penelitian Mucra (2011) dapat meningkatkan kandungan nutrisi serat buah kelapa sawit yaitu meningkatnya kandungan berat kering 91,40-92,73\%, protein kasar 5,68-8,41\%, serta menurunnya kandungan serat kasar 44,83-35,84\%, NDF 79,03-77,11\%, ADF 57,95-54,72\% dan lignin+cutin 21,65-19,24\%.

Tujuan penelitian adalah mengetahui pengaruh pemberian feses kerbau dengan level yang semakin meningkat sampai $30 \%$ terhadap SBKS fermentasi akan lebih mempengaruhi $\mathrm{pH}$, kualitas fisik fermentasi dan kandungan nutrisi SBKS.

\section{METODA PENELITIAN}

\section{Waktu dan Tempat}

Penelitian ini dilaksanakan pada bulan Januari sampai Maret 2013, di Laboratorium Nutrisi dan Kimia Fakultas Pertanian dan Peternakan UIN Suska Riau. Analisis kandungan gizi SBKS dilakukan di Laboratorium Nutrisi Ruminansia Fakultas Peternakan Universitas Andalas Padang.

\section{Bahan dan Alat}

Bahan yang digunakan adalah :

a. Bahan untuk fermentasi

Serat Buah Kelapa Sawit, diperoleh dari PT. Tunggal Perkasa Plantation LirikRiau. Feses kerbau, diperoleh dari ternak kerbau di Fakultas Pertanian dan Peternakan UIN Suska Riau. Aquadest, diperoleh dari Laboratorium Nutrisi dan Kimia Fakultas Pertanian dan Peternakan UIN SUSKA RIAU.

b. Bahan untuk analisis proksimat Bahan yang digunakan untuk analisis adalah aquadest, $\mathrm{HCl}, \mathrm{K}_{3} \mathrm{SO}_{4}, \mathrm{MgSO}_{4}$, $\mathrm{NaOH}, \mathrm{H}_{3} \mathrm{BO}_{4}$, Eter, Benzene, $\mathrm{CCl}_{4}$, katalisator selenium, dan ditambah dengan pelarut.

Analisis awal kandungan nutrisi materi penelitian ditampilkan pada Tabel 1 
Tabel 1. Komposisi Kimia SBKS dan Feses Kerbau.

\begin{tabular}{llccccccc}
\hline \multirow{2}{*}{ No } & \multirow{2}{*}{ Sampel } & \multicolumn{7}{c}{$(\%)$} \\
\cline { 2 - 9 } & & KA & BK & PK & LK & Abu & SK & BETN \\
\hline 1 & SBKS** & 8,34 & 91,66 & 4,36 & 3,58 & 5,61 & 32,19 & 54,26 \\
\hline 2 & Feses Kerbau* $^{*}$ & 5,31 & 16,38 & 5,83 & 14,00 & 8,77 & 24,00 & 47,40 \\
\hline
\end{tabular}

Sumber : * Hasil analisis Lab. Ilmu Nutrisi dan Kimia UIN Suska Riau (2012)

** Hasil analisis Lab. Nutrisi Ruminansia Fakultas Peternakan Unand Padang (2013)

Peralatan yang digunakan adalah sekop, timbangan, soil tester, termometer, alat-alat untuk fermentasi : baskom, plastik, selotip. Alat untuk analisis proksimat digunakan yaitu pemanas, gelas piala $300 \mathrm{ml}$, labu ukur, labu kjedhal, pipet gondok, soklet, kertas saring, tanur listrik, crusible tang, dan labu destilasi lengkap dengan Erlenmeyer.

\section{Metode Penelitian}

Penelitian menggunakan Rancangan Acak Lengkap (RAL) yang terdiri dari 4 perlakuan dan 3 ulangan. Perlakuan yang diberikan adalah sebagai berikut:
A. SBKS + aquadest (kontrol)
B. SBKS + Feses kerbau 10\% + aquadest
C. SBKS + Feses kerbau 20\% + aquadest
D. SBKS + Feses kerbau 30\% + aquadest

Masing-masing perlakuan difermentasi selama 3 minggu (21 hari).

Data yang diperoleh dianalisis dengan anova dan bila terdapat perbedaan yang nyata akan dilanjutkan dengan uji Duncan's Multipe Range Test (Steel dan Torrie, 1996).

\section{Parameter yang diukur}

1. Kualitas fisik fermentasi SBKS $(\mathrm{pH}$, warna , aroma, jamur, dan tekstur)

2. Kandungan nutrisi (bahan kering, protein kasar, serat kasar, lemak kasar, abu dan BETN)

\section{Prosedur Penelitian}

\section{Persiapan Materi Penelitian}

Serat buah kelapa sawit

Serat buah kelapa sawit diperoleh dari PT. Tunggal Perkasa Plantation kemudian ditimbang, dikering anginkan dan dibolak-balik sampai keringnya rata, setelah kering ditimbang kembali untuk menghitung berat kering anginnya.

\section{Feses kerbau}

Feses kerbau yang sudah diambil ditimbang, kemudian dikeringkan dengan panas matahari selama seminggu. Setelah kering proses berikutnya adalah feses kerbau dihaluskan atau dihancurkan menggunakan blender.

\section{Pencampuran bahan}

Perhitungan berdasarkan Bahan Kering (BK) dari SBKS dan Kadar Air (KA) yang diharapkan adalah $60-70 \%$.

$1 \mathrm{~kg}$ SBKS memiliki BK = 916,6 gr.

KA SBKS $=8,34 \%$

KA Fermentasi $=70 \%-8,34 \%=61,66 \%$

Aquadest $=916,6 \times 61,66 \%=565,17 \mathrm{ml}+$ $10 \%=621,69 \mathrm{ml}$

$\mathrm{SBKS}=1 \mathrm{~kg}$

Feses kerbau

$10 \% \mathrm{BK}=10 \% \times 916,6=91,66 \mathrm{~g}$

$20 \% \mathrm{BK}=20 \% \times 916,6=183,32 \mathrm{~g}$

$30 \% \mathrm{BK}=30 \% \times 916,6=274,98 \mathrm{~g}$

Aquadest $\quad=621,69 \mathrm{ml}$

Pencampuran dilakukan dalam bak plastik dengan mencampurkan SBKS, 
feses kerbau dan air setelah rata dicampurkan pada SBKS sehingga semua bahan tercampur dengan homogen.

1. Pembungkusan

Setelah semua bahan tercampur kemudian dimasukkan ke dalam kantong plastik berwarna hitam dan dipadatkan sehingga tercipta keadaan an-aerob, kemudian diikat dan dilapisi dengan plastik ke 2 selanjutnya plastik tersebut dimasukkan lagi ke dalam plastik ke 3, kemudian diikat lagi.
2. Tahap fermentasi

Fermentasi dilakukan selama 3 minggu (21 hari), selama fermentasi dilakukan pengukuran suhu, $\mathrm{pH}$ dan kualitas fermentasi diawal dan akhir fermentasi. Pengukuran suhu dan $\mathrm{pH}$ berfungsi sebagai acuan bahwa proses fermentasi berhasil dengan meningkatnya suhu dan turunnya $\mathrm{pH}$.

3. Analisis laboratorium, analisis dilakukan secara proksimat. Sampel yang dianalisis dihaluskan terlebih dahulu.

Bagan prosedur penelitian yang dilaksanakan disajikan pada Gambar 1.

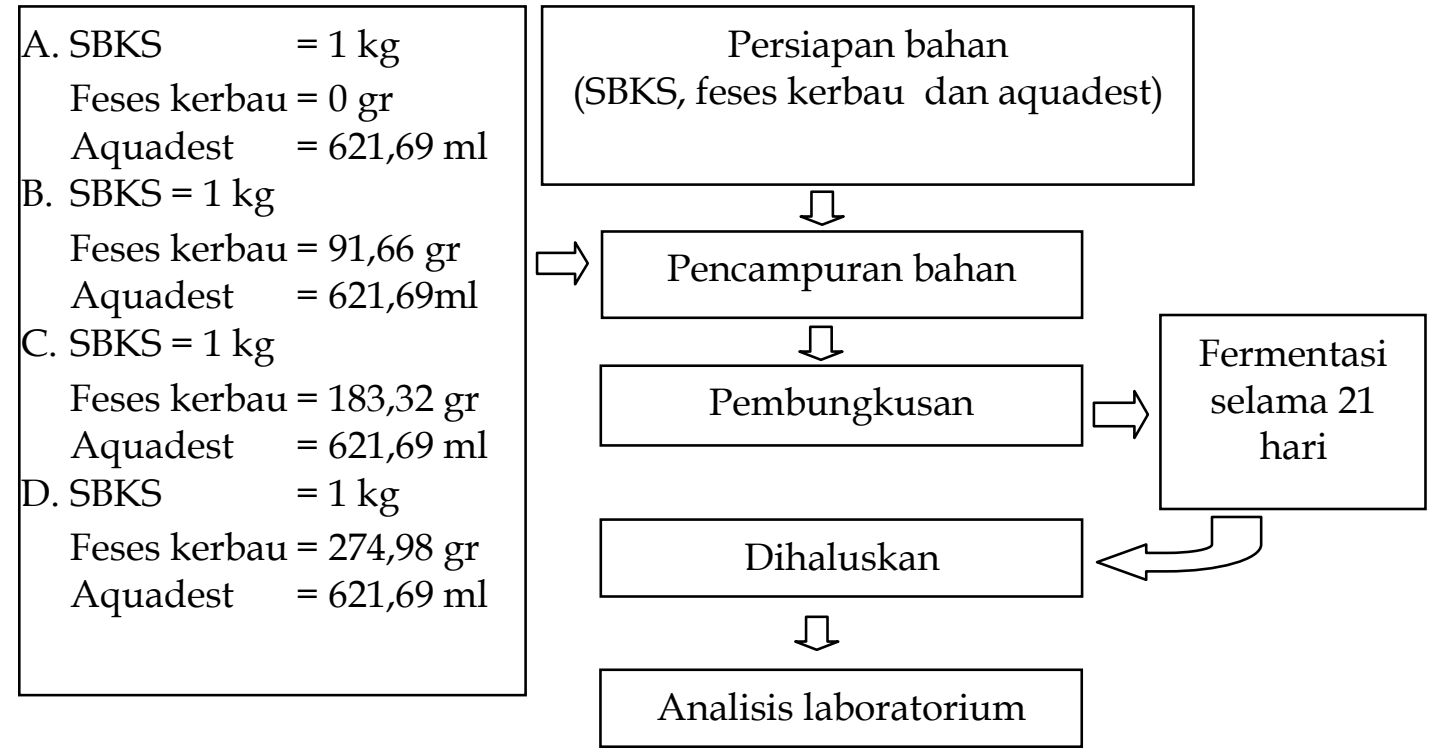

Gambar 1. Bagan Prosedur Penelitian 


\section{HASIL DAN PEMBAHASAN}

\section{pH dan Kualitas SBKS Fermentasi}

Hasil pengamatan fisik hasil fermentasi dapat dilihat pada Tabel 2.

Tabel 2. pH dan Kualitas SBKS Sebelum dan Setelah Fermentasi.

\begin{tabular}{|c|c|c|c|c|c|c|c|c|c|c|}
\hline \multirow{3}{*}{ Perlakuan } & \multicolumn{10}{|c|}{ Pengamatan Fermentasi SBKS } \\
\hline & \multicolumn{5}{|c|}{ Awal fermentasi } & \multicolumn{5}{|c|}{$\begin{array}{l}\text { Setelah Fermentasi } \\
\end{array}$} \\
\hline & $\mathrm{pH}$ & Aroma & Tekstur & Warna & Jamur & $\mathrm{pH}$ & Aroma & Tekstur & Warna & Jamur \\
\hline Feses $0 \%$ & 6,4 & Segar & Kasar & Coklat & $\begin{array}{c}\text { Tidak } \\
\text { ada }\end{array}$ & $3,7 \mathrm{c}$ & $\begin{array}{c}\text { Khas } \\
\text { fermentasi }\end{array}$ & Halus & $\begin{array}{c}\text { Coklat } \\
\text { keemasan }\end{array}$ & $\begin{array}{c}\text { Tidak } \\
\text { ada }\end{array}$ \\
\hline Feses $10 \%$ & 6,4 & Segar & Kasar & $\begin{array}{c}\text { Coklat } \\
\text { kehitaman }\end{array}$ & $\begin{array}{c}\text { Tidak } \\
\text { ada }\end{array}$ & $3,4^{\mathrm{b}}$ & $\begin{array}{c}\text { Khas } \\
\text { fermentasi }\end{array}$ & Halus & $\begin{array}{c}\text { Coklat } \\
\text { keemasan }\end{array}$ & $\begin{array}{c}\text { Tidak } \\
\text { ada }\end{array}$ \\
\hline Feses $20 \%$ & 6,5 & Segar & Kasar & $\begin{array}{c}\text { Coklat } \\
\text { kehitaman }\end{array}$ & $\begin{array}{c}\text { Tidak } \\
\text { ada }\end{array}$ & $3,3^{b}$ & $\begin{array}{c}\text { Khas } \\
\text { fermentasi }\end{array}$ & Halus & $\begin{array}{c}\text { Coklat } \\
\text { keemasan }\end{array}$ & $\begin{array}{c}\text { Tidak } \\
\text { ada }\end{array}$ \\
\hline Feses 30\% & 6,6 & Segar & Kasar & $\begin{array}{c}\text { Coklat } \\
\text { kehitaman }\end{array}$ & $\begin{array}{c}\text { Tidak } \\
\text { ada }\end{array}$ & $3,1^{a}$ & $\begin{array}{c}\text { Khas } \\
\text { fermentasi }\end{array}$ & Halus & $\begin{array}{c}\text { Coklat } \\
\text { keemasan }\end{array}$ & $\begin{array}{c}\text { Tidak } \\
\text { ada }\end{array}$ \\
\hline Signifikasi & ns & & & & & ** & & & & \\
\hline $\begin{array}{l}\text { Sumb } \\
\text { Keter }\end{array}$ & ngan & $\begin{array}{l}: \mathrm{ns} \mathrm{m} \\
* * \mathrm{~m}\end{array}$ & $\begin{array}{l}\text { torium } \\
\text { hunjukk } \\
\text { unjukka }\end{array}$ & $\begin{array}{l}\text { nu Nutrisi } \\
\text { pengaruh } \mathrm{p} \\
\text { pengaruh } \mathrm{p}\end{array}$ & $\begin{array}{l}\text { Kimi } \\
\text { lakua } \\
\text { lakuar }\end{array}$ & {$[N$} & $\begin{array}{l}\text { SKA Riau ( } \\
\text { rbeda nyata } \\
\text { sangat nyat }\end{array}$ & $\begin{array}{l}\text { 3). } \\
>0,05) \\
P<0,01)\end{array}$ & & \\
\hline
\end{tabular}

Hasil penelitian menunjukkan perlakuan SBKS fermentasi dengan penambahan feses kerbau sampai level $30 \%$ sangat nyata $(\mathrm{P}<0,01)$ menurunkan $\mathrm{pH}$ serat buah kelapa sawit (Tabel 2). Penurunan $\mathrm{pH}$ disebabkan oleh adanya aktifitas bakteri asam laktat. Hal ini sesuai dengan pendapat Merry dkk (1997), jika proses fermentasi berlangsung dengan sempurna, bakteri asam laktat (BAL) akan berkembang dan menjadi dominan, $\mathrm{pH}$ pada bahan fermentasi akan turun hingga 3,8 .

Penambahan feses kerbau 20\% tidak nyata $(\mathrm{P}>0,05)$ menurunkan kadar $\mathrm{pH}$ SBKS fermentasi dibandingkan dengan level $10 \%$. Hal ini disebabkan karena aktifitas mikroorganisme masih dalam fase stabil. Selain itu pada level 10\% dan $20 \%$ mengalami fase stasioner yang lebih panjang disebabkan kompetisi antara mikoroognanisme dengan substrat yang mengakibatkan penurunan $\mathrm{pH}$ yang tidak nyata $(\mathrm{P}>0,05)$. Hal ini sesuai dengan yang dikemukakan oleh Honig and Woolford (1980) bahwa sebagian besar jumlah mikroorganisme yang berkembang pada fase fermentasi akan berkurang secara perlahan. Beberapa jenis mikroorganisme toleran asam dapat bertahan dalam kondisi stasioner (inactive) pada fase ini, mikroorganisme lainnya seperti clostridia dan bacilli bertahan dengan menghasilkan spora.

Penambahan feses kerbau dengan level $30 \%$ nyata $(\mathrm{P}<0,05)$ menurunkan $\mathrm{pH}$ SBKS fermentasi dibandingkan dengan SBKS fermentasi pada level 20\%. Hal ini dikarenakan masih adanya mikro organisme yang masih bertahan dalam kondisi yang asam. Sesuai dengan yang disampaikan oleh Wemberg and Muck (1996) hanya beberapa jenis mikro organisme penghasil enzim protease dan carbohydrase toleran terhadap asam yang dapat menurunkan $\mathrm{pH}$. 
Menurut Merry dkk (1997), jika fermentasi berhasil dengan sempurna $\mathrm{pH}$ yang diperoleh dari fermentasi berkisar 3,8-5,0. Dari hasil penelitian didapat $\mathrm{pH}$ dari SBKS fermentasi berkisar 3,1-3,7 (sangat asam). Hal ini jauh berbeda dengan hasil penelitian Mucra (2007) $\mathrm{pH}$ SBKS fermentasi berkisar 4,49-4,94, diduga $\mathrm{pH}$ yang sangat asam mempengaruhi aktivitas mikroba bahkan terjadi kematian. Kondisi $\mathrm{pH}$ yang sesuai akan mempengaruhi aktivitas mikroba sehingga kandungan nutrisi SBKS meningkat.

SBKS yang difermentasi dengan feses kerbau sampai pada level berbeda terjadi perubahan $\mathrm{pH}$, aroma, tekstur dan warna dibandingkan dengan SBKS yang tidak difermentasi. Fermentasi akan terjadi beberapa proses yang sangat menguntungkan antara lain : menurunkan $\mathrm{pH}$, meningkatkan daya cerna, merubah tekstur, menambah flavor/rasa dan dapat menghilangkan zat anti nutrisi dan racun yang mungkin terkandung dalam bahan asal serta berfungsi sebagai pengawet (Mucra et al., 2009).

\section{Komposisi Kimia SBKS Fermentasi}

Rataan kadar bahan kering, protein kasar, serat kasar, lemak kasar, abu dan BETN serat buah kelapa sawit hasil fermentasi untuk masing-masing perlakuan ditampilkan pada Tabel 3.

Hasil penelitian ini (Tabel 3) menunjukkan penambahan level feses kerbau sampai $30 \%$ tidak dapat mempengaruhi kandungan nutrisi SBKS fermentasi secara signifikan $(\mathrm{P}>0,05)$.

Tabel 3. Komposisi Kimia SBKS yang difermentasi Feses Kerbau (\%BK)

\begin{tabular}{|c|c|c|c|c|c|c|}
\hline \multirow{2}{*}{ Perlakuan } & \multirow{2}{*}{ BK } & \multicolumn{5}{|c|}{ Bahan Kering } \\
\hline & & PK & SK & LK & Abu & BETN \\
\hline Feses $0 \%$ & 97,62 & 12,04 & 36,67 & 6,35 & 9,24 & 35,70 \\
\hline Feses 10\% & 97,88 & 12,56 & 35,79 & 6,34 & 9,68 & 35,63 \\
\hline Feses 20\% & 98,19 & 14,79 & 36,40 & 6,06 & 9,82 & 32,94 \\
\hline Feses 30\% & 97,69 & 12,35 & 35,44 & 6,26 & 10,83 & 35,11 \\
\hline Signifikasi & ns & ns & ns & ns & ns & ns \\
\hline
\end{tabular}

Kadar bahan kering SBKS fermentasi berkisar 97,62\%-97,69\% menunjukkan penambahan feses kerbau sampai level $30 \%$ memberikan pengaruh tidak nyata $(\mathrm{P}>0,05)$ terhadap kandungan bahan kering SBKS fermentasi.

Hasil penelitian ini menunjukkan kadar bahan kering dari hasil fermentasi SBKS lebih tinggi dari pada hasil penelitian yang dilaporkan Kholid (2009) yaitu 85,79\% dan Mucra (2011) yaitu 92,73\%. Tingginya kandungan BK SBKS fermentasi hasil penelitian ini disebabkan oleh penambahan level feses kerbau sampai $30 \%$ juga menyumbangkan BK yang lebih banyak pula dari feses kerbau dan aktivitas dari mikroba itu sendiri.

Suparjo et al. (2009) menyatakan perbanyakan jumlah miselium dari mikroba sebagai indikator pertumbuhan selama proses fermentasi yang menyebabkan meningkatnya bahan kering. Surono et al. (2006) menyatakan peningkatan kandungan bahan kering pada pengolahan pakan dipengaruhi oleh penurunan kadar air.

Penambahan feses kerbau sampai level $30 \%$ tidak nyata $(\mathrm{P}>0,05)$ mempengaruhi kadar protein kasar SBKS fermentasi. 
Tidak meningkatnya kandungan PK SBKS fermentasi secara nyata diduga pada level $30 \%$ mikroba di dalam feses kerbau kurang berkembangbiak dan tidak tumbuh secara baik karena $\mathrm{pH}$ yang sangat asam (3,1-3,7) dan jumlah mikroorganisme yang semakin banyak dengan bertambahnya level feses yang diberikan menyebabkan nutrien yang dimanfaatkan semakin sedikit dan lama kelamaan mikroorganisme akan mati. Pada penelitian Mucra (2011) SBKS yang difermentasi menggunakan feses kerbau sampai level $6 \%$ sudah signifikan menaikkan protein kasar disebabkan $\mathrm{pH}$ dari SBKS fermentasi 4,49-4,94 sangat mendukung aktivitas mikroorganisme.

Keberhasilan produk fermentasi harus diikuti dengan $\mathrm{pH}$ yang menunjang dan sesuai terhadap pertumbuhan mikro organisme. Sesuai dengan pendapat Merry (1997) bahwa hasil fermentasi yang baik jika memenuhi syarat $\mathrm{pH}$ yaitu 4,5-5. Sandi et al. (2010) menyatakan laju kecepatan penguraian protein (proteolisis) sangat tergantung pada penurunan $\mathrm{pH}$ yang turun pada awal masa pengolahan pakan.

Adanya peningkatan protein kasar dari fermentasi SBKS disebabkan oleh perbanyakan miselium mikroorganisme. Sesuai dengan Nelson dan Suparjo (2011) bahwa peningkatan kandungan protein disebabkan karena biokonversi menjadi protein sel tunggal. Semakin banyak miselium akibat aktivitas mikroba semakin banyak nitrogen tubuh dan merupakan sumbangan protein bagi substrat yang difermentasi (Musnandar, 2003).

Penambahan feses kerbau sampai 30\% tidak nyata $(\mathrm{P}>0,05)$ menurunkan kadar serat kasar SBKS fermentasi. Hasil penelitian Mucra (2011) SBKS fermentasi menggunakan feses kerbau sampai level $6 \%$ nyata menurunkan serat kasar SBKS fermentasi.
Tidak terjadinya penurunan SK SBKS fermentasi menggunakan feses kerbau sampai 30\% ini disebabkan oleh aktifitas mikroba yang bersifat selulolitik belum optimal untuk merenggangkan ikatan lignoselulosa dan hemiselulosa dari SBKS fermentasi karena jumlah mikroba yang banyak sejalan dengan penambahan level feses kerbau sampai 30\% menjadikan suasana $\mathrm{pH}$ yang sangat asam yang mengakibatkan populasi mikroorganisme dan sumber energi semakin sedikit.

Faktor - faktor yang mempengaruhi kerja enzim dari mikroorganisme meliputi suhu dan $\mathrm{pH}$. Hasil penelitian didapatkan kadar pH SBKS fermentasi berkisar 3,1-3,7 menunjukkan SBKS dalam kondisi asam. Meryandini dkk, (2009) menyatakan aktivitas enzim dipengaruhi oleh $\mathrm{pH}$, karena sifat ionik gugus karboksil dan gugus amino mudah dipengaruhi oleh $\mathrm{pH}$. Perubahan $\mathrm{pH}$ atau $\mathrm{pH}$ yang tidak sesuai akan menyebabkan daerah katalitik dan konformasi enzim berubah. Selain itu perubahan $\mathrm{pH}$ juga menyebabkan denaturasi enzim dan mengakibatkan hilangnya aktivitas enzim. Bakteri yang terdapat dalam fermentasi (proteolitik, selulolitik dan lignolitik) memiliki $\mathrm{pH}$ optimum 4,5 dan 5 dengan rentang $\mathrm{pH}$ 4- 9 dan mencapai aktivitas tertinggi pada suhu $70^{\circ} \mathrm{C}$ (Meryandini dkk, 2009).

Dhalika et al. (2011) menyatakan serat kasar dari pengolahan pakan merupakan komponen dari karbohidrat yang lebih sederhana akibat dari pertumbuhan mikroba membentuk asam laktat. Santi et al. (2011) menjelaskan kadar serat kasar yang rendah dapat disebabkan oleh adanya panas fermentasi dan $\mathrm{pH}$ yang rendah dari asam organik yang menyebabkan komponen-komponen karbohidrat dari serat kasar mengalami hidrolisis sehingga banyak bagian yang terlarut.

Penambahan feses kerbau sampai level $30 \%$ tidak berbeda nyata $(\mathrm{P}>0,05)$ 
menurunkan kadar lemak kasar karena tidak sesuainya sifat mikroba yang berkembang dalam proses fermentasi SBKS, sehingga pemecahan lemak menjadi asam lemak tidak banyak terjadi. Selama proses fermentasi bakteri yang dominan terjadi adalah berkembangnya BAL yang menghasilkan asam laktat dan bukan menghasilkan enzim lipase, yang dapat menurun serat kasar dari produk fermentasi. Sesuai dengan yang dinyatakan oleh Chen dan Weinberg (2008) yaitu fermentasi yang baik didominasi oleh BAL dan menghasilkan konsentrasi asam organik yang didominasi oleh asam laktat.

Hasil penelitian ini didapat kadar lemak yang lebih rendah dibandingkan dengan yang dilaporkan Mucra (2007) bahwa lemak kasar dari SBKS fermentasi yang digunakan sampai level 6\% yaitu $7,60 \%$ dan belum juga dapat menurunkan lemak kasar secara nyata $(P>0,05)$. Dhalika et al. (2011) tidak banyak terjadinya perubahan kandungan lemak kasar pada fermentasi pakan dipengaruhi oleh BAL yang tidak terlalu banyak membutuhkan lemak untuk pertumbuhan dan perkembangannya.

Pemberian feses kerbau sampai level $30 \%$ pada SBKS fermentasi tidak nyata $(\mathrm{P}>0,05)$ mempengaruhi kadar abu hal ini diduga substrat/bahan yang digunakan dalam fermentasi mengandung mineral yang berbeda pula dan penambahan feses kerbau sejalan dengan mineral yang disumbangkan sehingga kadar abu juga semakin meningkat.

Hal ini menyebabkan pada penelitian ini kadar abu lebih tinggi (9,24\%-10,83\%) dibandingkan yang dilaporkan Mucra (2007) kadar abu yang diperolah dari SBKS fermentasi sampai level 6\% yaitu $5,84 \%$. Hal ini sesuai yang disampaikan oleh Wina (2001) abu merupakan komponen anorganik yang tersusun atas mineral $\mathrm{Ca}, \mathrm{P}$, dan lainnya yang berfungsi mendukung perkembangan dari BAL.

Penambahan feses kerbau sampai level $30 \%$ pada SBKS yang difermentasi dengan feses kerbau tidak nyata $(\mathrm{P}>0,05)$ meningkatkan kadar BETN. Hal ini terjadi karena tidak nyatanya $(\mathrm{P}>0,05)$ pemberian level feses kerbau sampai 30\% terhadap kandungan BK, PK, SK, LK dan Abu juga sejalan dengan kandungan BETN karena apabila jumlah PK, SK, LK dan abu yang didapat rendah maka jumlah BETN semakin tinggi begitu juga sebaliknya.

Dari hasil penelitian didapat kadar BETN yang lebih rendah dari penelitian Mucra (2007) kadar BETN 42,56\%, sementara hasil penelitian ini kandungan BETN adalah 35,69\%-32,93\% hasil ini didapat karena kadar serat kasar hasil penelitian yang didapat masih tinggi berkisar 36,40\%-35,44\% dan kadar protein kasar juga tinggi yaitu 12,36\%-14,79\% sehingga pengurangan kadar BETN cukup besar. Kusumaningrum dkk. (2011) menyatakan BETN dapat dikatakan sebagai karbohidrat terlarut, kebalikannya dengan serat kasar yang merupakan polisakarida yang tidak larut yang akan mempengaruhi nilai BETN.

\section{KESIMPULAN DAN SARAN}

\section{Kesimpulan}

Penambahan feses kerbau sampai level $30 \%$ pada SBKS fermentasi tidak mampu mempengaruhi nilai gizi (BK, PK, SK, LK, Abu dan BETN), tetapi dapat menurunkan nilai $\mathrm{pH}$.

\section{Saran}

Perlu dilakukan penelitian lebih lanjut dengan mengkombinasikan dengan teknik lain seperti fisik dam kimia sehingga dapat meningkatkan kualitas SBKS. 


\section{DAFTAR PUSTAKA}

Aunstrup, K. 1979. Production Isolation Economic of Extracelluler Enzyms. Cited C.E. Wingard, E.K. Katzir and Gold Steinceds. Applied Biochemitry Bioenginering Technology. Academic Press. New York.

Azriani. 2009. Komposisi Kimia Daun Kelapa Sawit yang difermentasi dengan Inokulum Berbeda. Skripsi. Fakultas Pertanian dan Peternakan UIN Suska Riau. Pekanbaru.

Banerjee, G. C. 1978. Animal Nutrition. Oxford and IBN Publishing Co. Calcutta.

BPS. 2014. Riau dalam Angka. Pekanbaru: Badan Pusat Statistik Provinsi Riau.

BPS. 2015. Riau dalam Angka. Pekanbaru: Badan Pusat Statistik Provinsi Riau.

Dhalika, T. Mansyur dan A.R, Tarmidi. 2011. Nilai Nutrisi Batang Pisang dan Produk Bioproses (Ensilage) sebagai Ransum Lengkap. Jurnal Ilmu Ternak. 11(1): 17-23.

Febrina, D., S. I. Zam dan A. Fatah. 2011. Isolasi dan Identifikasi Bakteri yang Berperan dalam Proses Fermentasi Menggunakan Feses Sapi pada Ransum Berbahan Limbah Perkebunan Kelapa Sawit. Prosiding Seminar Nasional Green Tech II. Fakultas Sains dan Teknologi. Universitas Islam Negeri Maulana Malik Ibrahim. Malang.

Honig, H and M. K. Woolford. 1980. Changes in Silage on Exposure to Air. Occasional Symposium of the British Grassland Society, No. 11, pp. 76-87.

Jonathan S.G., I.O Fasidi., A.O Ajayi., A Adegeye. 2008. Biodegradation of Nigerian Wood Waste by Pleurotus Tuber-Regium (Fries) Singer. Bioresorce and Tecknology 99:807-811.

Kholid, E. 2009. Komposisi Kimia Daun Kelapa Sawit yang difermentasi dengan Feses Ayam pada Level Berbeda. Skripsi.
Fakultas Pertanian dan Peternakan UIN Suska Riau. Pekanbaru.

Kusumaningrum, M., Sutrisno, C. I dan Prasetyono, B. W. H. E. 2012. Kualitas Kimia Ransum Sapi Potong Berbasis Limbah Pertanian dan Hasil Samping Pertanian yang Difermentasi dengan Aspergillus Niger. Animal Agriculture Journal. 1:109-119.

Merry R. J, K. F. Lowes., A. L. Winters. 1997. Current and Future Approaches to Biocontrol in Silages. Forage Conservation: 8th International Scientific Symposium, Pohořelice: Research Institute of Animal Nutrition. Czech Republic, pp. 17-27.

Meryandini, A., W. Widosari., B. Maranatha., T. C. Sunarti., N. Rachmania., dan H. Satria. 2009. Isolasi Bakteri Selulolitik dan Karakterisasi Enzimnya. Makara Sains. 13 (1): 33-38.

Mucra, D. A. 2007. Pengaruh Fermentasi Serat Buah Kelapa Sawit terhadap Komposisi Kimia dan Kecernaan Nutrien secara Invitro. Tesis Pascasarjana UGM. Yogyakarta.

Mucra, D. A. 2011. Komposisi Kimia dan Fraksi Serat dari Serat Buah Kelapa Sawit yang difermentasi dengan Feses Kerbau. Proceeding of National Seminar on Zootechniques for Indogenous Resources Development. Faculty of Animal Agriculture Diponegoro University., Indonesian Society of Animal Agriculture. Semarang.

Mucra, D. A., S. P. S. Budhi and A. Agus. 2009. Fermentation of Palm Press Fiber and Its Effect on Chemical Composition and In Vitro Digestibility. Proceeding International Conference Agricultural and Livestock Production Based on Agroindustry. Pekanbaru.

Musnandar, E. 2003. Pengaruh Dosis Inokulum Marasmius sp. dan Lama Inkubasi terhadap Kandungan Komponen Serat dan Protein Murni pada Sabut Kelapa Sawit untuk Bahan Pakan 
Ternak. Jurnal Ilmiah Ilmu-Ilmu Peternakan. IX(4).

Nelson dan Suparjo. 2011. Penentuan Lama Fermentasi Kulit Buah Kakao dengan Phanerochaete chrysosporium, Evaluasi Kualitas Nutrisi secara Kimiawi. Agrinak. 1 (1): 1-10.

Rahayu, S. 2013. Isolasi Bakteri Selulolitik yang Berperan pada Proses Fermentasi Menggunakan Feses Kerbau pada Ransum Berbahan Limbah Perkebunan Kelapa Sawit. Skripsi. Fakultas Pertanian dan Peternakan UIN Suska Riau.

Sandi, S. E. B. Laconi. A. Sudarman, K. G. Wiryawan dan D. Mangundjaja. 2010. Kualitas Silase Berbahan Baku Singkong yang Diberi Enzim Cairan Rumen Sapi dan Leucanostoc mesenteroides. Media Peternakan. 33(1):25-30.

Santi, R. K. D. Widyawati, W. P. S. dan Suprayogi. 2011. Kualitas dan Nilai Kecernaan In Vitro Silase Batang Pisang (Musa paradisiaca) dengan Penambahan Beberapa Akselator. Jurnal Tropical Animal Husbandry. 1(1):15-23.
Steel, R. G. D., dan J. H. Torrie. 1996. Prinsip dan Prosedur Statistika. Edisi ke-4. Penerbit Gramedia Pustaka Utama, Jakarta. (Diterjemahkan oleh B. Sumantri).

Suparjo., K.G.Wiryawan., E.B. Laconi dan D. Mangunwijaja. 2009. Perubahan Komposisi Kimia Kulit Buah Kakao akibat Penambahan Mangan dan Kalsium dalam Biokonversi dengan Kapang Phanerochaete chrysosporium. Media Peternakan. 32(3):204-211.

Weinberg, Z. G and R. E. Muck. 1996. New Trends and Opportunities in the Development and Use of Inoculants for Silage. FEMS Microbiol. Rev., 19: 53-68. 